\title{
Growth status of first grader children in elementary schools in Watu Alo, Manggarai, East Nusa Tenggara
}

\author{
Dwi Lestari Pramesti ${ }^{1 *}$, Srisadono Fauzi Adiwibowo ${ }^{1}$, Komang Ferdiana $^{1}$, Ria Ramadhani ${ }^{1}$, Hardian Gunardi ${ }^{1}$, \\ Aman Pulungan ${ }^{1,2}$
}

From 8th APPES Biennial Scientific Meeting

Darwin, Australia. 29 October - 1 November 2014

\section{Background}

East Nusa Tenggara (NTT) had the highest number of children under five with mild to severe malnutrition in Indonesia, happened mostly in Manggarai Regency, with the highest number of cases found in Watu Alo Primary Health Care Supervision Area, with 5 out of all 19 cases in Manggarai, NTT (RISKESDAS, 2010). Nevertheless the method to classify the growth status was unclear.

\section{Objective}

To determine growth status of first grader children in Watu Alo, Manggarai, NTT using the WHO and CDC growth charts and comparing the results.

\section{Method}

A cross-sectional descriptive study. The data was taken from 19 to 22 August 2013 and 24 August 2013 in 5 elementary school under the supervision of Watu Alo Primary Health Care, Manggarai Regency, East Nusa Tenggara. Data interpretation with CDC and WHO growth chart.

\section{Results}

CDC: the children are $74 \%$ short; $26 \%$ normal stature (median: $109 \mathrm{~cm}$ ), 21.9\% underweight; 69.4\% normal weight; $6.1 \%$ overweight; and $2.6 \%$ obese (median: $18 \mathrm{~kg}$ ). WHO: $72.4 \%$ of the children are normal stature; $20.9 \%$ stunted; $6.6 \%$ severely stunted, $84.7 \%$ normal weight; $6.6 \%$ risk of overweight; $6.6 \%$ wasted; $1 \%$ overweight; $0.5 \%$ obese; $0.5 \%$ severe wasted.

University of Indonesia, Jakarta, Indonesia

Full list of author information is available at the end of the article

\section{Conclusions}

To interpret the growth status, clinical judgement is also needed to be considered. Children growth status should be monitored continuously. Standardized national growth chart for Indonesian children should be made.

\section{Authors' details}

'University of Indonesia, Jakarta, Indonesia. ${ }^{2}$ Cipto Mangunkusumo Hospital Jakarta, Indonesia.

Published: 28 April 2015

doi:10.1186/1687-9856-2015-S1-P35

Cite this article as: Pramesti et al:: Growth status of first grader children in elementary schools in Watu Alo, Manggarai, East Nusa Tenggara. International Journal of Pediatric Endocrinology 2015 2015(Suppl 1):P35.
Submit your next manuscript to BioMed Central and take full advantage of:

- Convenient online submission

- Thorough peer review

- No space constraints or color figure charges

- Immediate publication on acceptance

- Inclusion in PubMed, CAS, Scopus and Google Scholar

- Research which is freely available for redistribution

Submit your manuscript at www.biomedcentral.com/submit
() Biomed Central 